\title{
Do greenhouse gases impact our respiratory system? A study of the effect of greenhouse gas emissions on respiratory disease related mortality in Ireland
}

Anushree Priyadarshini

Technological University Dublin, anushree.priyadarshini@tudublin.ie

Christina Kenny

Technological University Dublin

Follow this and additional works at: https://arrow.tudublin.ie/creaart

Part of the Engineering Commons

\section{Recommended Citation}

Priyadarshini, A. \& Kenny, C. (2020)Do greenhouse gases impact our respiratory system? A study of the effect of greenhouse gas emissions on respiratory disease related mortality in Ireland,Proceedings 2020, 4, $x$; doi: FOR PEER REVIEW

This Conference Paper is brought to you for free and open access by ARROW@TU Dublin. It has been accepted for inclusion in Articles by an authorized administrator of ARROW@TU Dublin. For more information, please contact arrow.admin@tudublin.ie, aisling.coyne@tudublin.ie,gerard.connolly@tudublin.ie.

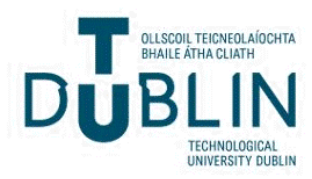


Proceedings

\title{
Do greenhouse gases impact our respiratory system? A study of the effect of greenhouse gas emissions on respiratory disease related mortality in Ireland
}

\author{
Christina Kenny ${ }^{1}$ and Anushree Priyadarshini ${ }^{1,2}$ \\ ${ }^{1}$ College of Business, Technological University Dublin, Aungier Street, Dublin 2, Ireland, D18125471@my- \\ tudublin.ie \\ 2 Environment Sustainability and Health Institute, Technological University Dublin, , Dublin, Ireland, \\ anushree.priyadarshini@tudublin.ie \\ * Correspondence: d18125471@mytudublin.ie.
}

Publisher's Note: MDPI stays neutral with regard to jurisdictional claims in published maps and institutional affiliations.

CC)
Copyright: $\odot 2020$ by the authors.
Submitted for possible open access
publication under the terms and
conditions of the Creative Commons
Attribution (CC BY) license
(http://creativecommons.org/li-
censes/by/4.0/).

\begin{abstract}
Respiratory-related deaths are one of the major causes of morbidity and mortality every year in the developed world. Previous research outlines that greenhouse gas emission levels have a negative effect on respiratory health and can cause worsening of symptoms. This study examines the impact of greenhouse gas emissions on respiratory disease related mortality in Ireland from 2007-2017 using Statbank data from Central Statistics Office, Ireland. Analysis shows that over the last decade, while greenhouse gases emissions in Ireland have reduced by $1.1 \%$, respiratory disease related mortality has increased on an average by $2.1 \%$. Results indicate that greenhouse gas emissions have no significant relationship $(\mathrm{p}>0.05)$ with deaths as a result of respiratory diseases, indicating that the increasing levels of respiratory disease related mortality in Ireland cannot be attributed to greenhouse gas emissions.
\end{abstract}

Keywords: GHG emissions; Respiratory diseases; Mortality

\section{Introduction}

\subsection{The global burden of respiratory disease.}

The World Health Organisation (WHO) defines 'chronic' or 'non-communicable disease' as diseases of 'long duration and are the result of a combination of genetic, physiological, environmental and behaviour factors' and state that chronic diseases are currently at epidemic proportions being responsible for 40,545 deaths worldwide in 2016, responsible for 1.5 million Disability Adjusted Life Years (DALYS) in 2016 [1] and nearly two thirds of all deaths globally [2]. The number of people living with and dying from chronic diseases is expected to increase along with the increase in the geriatric population. While people are living longer, more people are dying of chronic diseases than ever before.

Along with the possibility of immense morbidity and mortality, chronic diseases have even more acute, widespread effects on society as a whole with many of them accounting for huge losses in corporate productivity amongst other things. The world health economic forum estimated that between the years 2011 and 2030 there will be a cumulative output loss of 47 trillion US dollars due to non-communicable diseases [3].

Among such chronic diseases, respiratory disease poses a major threat to global health [4]. By 2017, around 544.9 million people worldwide had some form of chronic respiratory disease, this is almost an increase of $40 \%$ on the 1990 figure [5]. Among respiratory diseases Asthma and Chronic Obstructive Respiratory Disease (COPD) are amongst the biggest causes of mortality. It is estimated that some 339 million people and 251 million people respectively are living with the conditions worldwide [6-7]. In 2015, about 3,17 million people died of COPD, accounting for 5\% of the total deaths that year. Similarly, in 2016 there were 417,918 deaths attributed to Asthma [5]. One of the main 
contributors to respiratory morbidity and mortality is greenhouse gas (GHG) emissions and air pollution. Many of the chemicals found in GHGs have been found to cause significant harm to patients with pre-existing lung conditions [8].

\subsection{Respiratory disease and GHG emissions.}

The growing burden of global air pollution as a result of greenhouse gases is major public health concern. In 2012 alone, about 3.7 million people died of conditions related to ambient global air pollution. This figure is a 3 -fold increase from its 2008 equivalent [9]. Air pollution can be further subdivided into indoor and outdoor pollution depending on the location of the gases produced. Indoor air pollution can stem from tobacco combustion, fuel combustion, remodeling and demolition of surfaces, coal combustion, fumes from cooking consumer products and construction materials. Such sources of pollution can produce numerous forms of pollutants such as fine particles, carbon monoxide, sulphur oxides, arsenic, aldehydes, asbestos, lead, radon and nitrogen oxide [10]. Outdoor pollutants are present on a much larger scale and often originate from industrial and agricultural activities. Examples of common outdoor pollutants include: Carbon monoxides, sulphur oxides, ozone, Nitrogen oxides, volatile organic pollutants and bioaerosols [11].

Air pollution as a result of greenhouse gases can affect every part of the human body and can result in a wide range of diseases and disorders affecting various organs and organ systems [12] Air pollution is particularly triggering for respiratory conditions including Asthma, COPD and even lung cancer and because of this global governments, including Ireland, have made reducing air pollutants a primary goal for their respective countries. In recent years there has been a growing need for the improved management of chronic conditions due to the immense personal, societal and economic strain they place on individuals and governments alike and as such, the negative impact of GHGs on chronic lung conditions is a prime focus of research and legislation [3] with policy makers placing heavy priority on it [13]. As the link between respiratory mortality and increasing GHG emissions has been widely established [14] this study aimed to examine that potential association in more detail in Ireland.

\section{Methods}

In order to examine this association between GHG emissions and respiratory mortality this study examines the impact of GHG emissions on respiratory disease related mortality in Ireland from 2007-2017. Statbank data on GHG emissions and on mortality due to respiratory diseases in Ireland during the aforementioned period is used for the analysis.

\section{Results and Discussion}

Correlation analysis demonstrates that over the last decade, while GHG emissions in Ireland have reduced by $1.1 \%$, respiratory disease related mortality has increased on an average by $2.1 \%$. Respiratory deaths recorded a notable increase in figures from 2015-2017 with previous year's figures remaining notably more stable (Table 1). Overall, female deaths were recorded in higher numbers every year with female deaths recording a $9 \%$ higher figure than male deaths in 2017 despite previous studies recording no significant difference between genders [15]. Total emissions were at their highest in 2016 and 2017 and at their lowest in 2011. A bivariate Pearson correlation demonstrated no significant relationship ( $\mathrm{p}>0.05)$ with deaths as a result of respiratory diseases from overall GHG emissions (GHG 000 Tonnes CO2 Equivalents) (Table 2). Similarly, a bivariate Pearson correlation demonstrated no significant relationship $(p>0.05)$ between respiratory deaths between 2007 and 2017 for any of the primary GHG emission levels recorded including Methane, Nitrous Oxide or Carbon Dioxide (Table 3). 
Table 1. Respiratory Deaths and from 2007-2017.

\begin{tabular}{ccc}
\hline Year & $\begin{array}{c}\text { Number Respiratory } \\
\text { Deaths }\end{array}$ & GHG 000 Tonnes CO2 Equivalents \\
\hline 2007 & 3324 & 68,537 \\
2008 & 3522 & 64,038 \\
2009 & 3606 & 61547 \\
2010 & 3280 & 61105 \\
2011 & 3438 & 56989 \\
2012 & 3497 & 57612 \\
2013 & 3504 & 57410 \\
2014 & 3492 & 57099 \\
2015 & 3865 & 59212 \\
2016 & 3935 & 61270 \\
2017 & 4059 & 60744 \\
\hline
\end{tabular}

Table 2. The Pearson Bivariate Correlation of Respiratory deaths and GHG emissions.

\begin{tabular}{|c|c|c|c|}
\hline & & $\begin{array}{l}\text { RESPIRATORY } \\
\text { DEATHS }\end{array}$ & $\begin{array}{l}\text { GHG } 000 \text { TONNES } \\
\text { C02 EQUIVALENTS }\end{array}$ \\
\hline \multirow{3}{*}{$\begin{array}{l}\text { RESPIRATORY } \\
\text { DEATHS }\end{array}$} & Pearson Correlation & 1 & -0.127 \\
\hline & Sig (2-tailed) & & 0.709 \\
\hline & $\mathbf{N}$ & 11 & 11 \\
\hline \multirow{3}{*}{$\begin{array}{l}\text { GHG } 000 \text { TONNES } \\
\text { C02 EQUIVALENTS }\end{array}$} & Pearson Correlation & -0.127 & 1 \\
\hline & Sig (2-tailed) & 0.709 & \\
\hline & $\mathbf{N}$ & 11 & 11 \\
\hline
\end{tabular}

Table 3. The Pearson Bivariate Correlation significance values (2-talied) for all three gases and the corresponding death numbers between 2007-2017.

\begin{tabular}{rlll}
\hline & $\begin{array}{l}\text { Respiratory deaths } \\
\text { and Carbon dioxide } \\
\text { Tonnes C02 Equiva- } \\
\text { lent }\end{array}$ & $\begin{array}{l}\text { Respiratory deaths } \\
\text { and Nitrous Oxide } \\
\text { Tonnes C02 Equiva- } \\
\text { lent }\end{array}$ & $\begin{array}{l}\text { Respiratory deaths } \\
\text { and Methane Tonnes } \\
\text { C02 Equivalent }\end{array}$ \\
\hline $\begin{array}{r}\text { Pearson Signifi- } \\
\text { cance (2-talied) p- } \\
\text { value }\end{array}$ & 0.351 & 0.786 & 0.536 \\
\hline
\end{tabular}

While previous studies [13;16] indicate a clear relationship between respiratory mortality and GHG emission levels this study demonstrates that in Ireland, between the 10year period of 2007-2017 there is no significant statistical correlation between the two. This, however, does not mean that GHGs do not play a notable, negative role in respiratory health but instead, in this case likely demonstrates that GHGs alone cannot account for respiratory deaths during the period. In order to gain a more in-depth understanding of the relationship between GHG emissions and respiratory death, other variables will have to be taken into account and further analysed. Such variables may include: other health risk factors, lifestyle factors, relative, total GHG emissions and respiratory deaths broken down by region. Such factors should not be overlooked as indoor air pollution has been demonstrated to have an effect in lung cancer rates as well as acute respiratory infection rates [17] and indoor air pollution figures have not been included in this analysis. Studies can also examine the specific breakdown of the GHG emissions to get a clearer 
understanding of which elements of GHGs may be attributed to increased respiratory death [18].

\section{Conclusion}

While many respiratory deaths can and are attributed to GHG emissions, no statistical significance can be established between the two in Ireland during the 10-year period examined here and henceforth we cannot say that these deaths were attributed to an increase in GHG emissions alone. Further studies are required to examine any potential correlations more closely including a range of internal and external variables.

\section{References}

[1] World Health Organisation. (2018). Chronic Rheumatic conditions [Online]. Available at: http://www.who.int/chp/topics/rheumatic/en/ [Accessed 18 December 2020].

[2] Bauer, U. E., Briss, P. A., Goodman, R. A., \& Bowman, B. A. (2014). Prevention of chronic disease in the 21st century: elimination of the leading preventable causes of premature death and disability in the USA. The Lancet, 384(9937), 45-52. doi:10.1016/s0140-6736(14)60648-6

[3] Bloom et al. (2011). The global economic burden of non-communicable diseases. World Economic forum. [Online]. Available at: http://www.weforum.org/reports/global-economic-burden-non-communicable-diseases. [Accessed: 26 Oct 2018].

[4] Viegi, G., Maio, S., Fasola, S., \& Baldacci, S. (2020). Global Burden of Chronic Respiratory Diseases. Journal of Aerosol Medicine and Pulmonary Drug Delivery. doi:10.1089/jamp.2019.1576

[5] Soriano, J. B., Kendrick, P. J., Paulson, K. R., Gupta, V., Abrams, E. M., Adedoyin, R. A., ... Ahmadian, E. (2020). Prevalence and attributable health burden of chronic respiratory diseases, 1990-2017: a systematic analysis for the Global Burden of Disease Study 2017. The Lancet Respiratory Medicine, 8(6), 585-596. doi:10.1016/s2213-2600(20)30105-3

[6] World Health Organisation. (2020). Asthma [Online]. Available at: https://www.who.int/en/news-room/fact-sheets/detail/asthma [Accessed 18 December 2020].

[7] World Health Organisation. (2017). COPD [Online]. Available at: https://www.who.int/en/news-room/fact-sheets/detail/chronicobstructive-pulmonary-disease-(copd) [Accessed 18 December 2020].

[8] Joshi, M., Goraya, H., Joshi, A., \& Bartter, T. (2019). Climate change and respiratory diseases. Current Opinion in Pulmonary Medicine, 1. doi:10.1097/mcp.0000000000000656

[9] Jiang, X. Q., Mei, X. D., \& Feng, D. (2016). Air pollution and chronic airway diseases: what should people know and do?. Journal of thoracic disease, 8(1), E31-E40. https://doi.org/10.3978/j.issn.2072-1439.2015.11.50

[10] Zhang, J. (Jim), \& Smith, K. R. (2003). Indoor air pollution: a global health concern. British Medical Bulletin, 68(1), 209-225. doi:10.1093/bmb/ldg029

[11] Curtis, L., Rea, W., Smith-Willis, P., Fenyves, E., \& Pan, Y. (2006). Adverse health effects of outdoor air pollutants. Environment International, 32(6), 815-830. doi:10.1016/j.envint.2006.03.012

[12] Carey IM, Atkinson RW, Kent AJ, van Staa T, Cook DG, Anderson HR. (2013). Mortality associations with long-term exposure to outdoor air pollution in a national English cohort. Am J Respir Crit Care Med ;187(11):1226-33. doi: 10.1164/rccm.201210-1758OC. PMID: 23590261; PMCID: PMC3734610.

[13] Haines, A., McMichael, A., Smith, K., Roberts, I., Woodcock, J., Markandya, A., Armstrong, B., Campbell-Lendrum, D., Dangour, A., Davies, M., Bruce, N., Tonne, C., Barrett, M \& Wilkinson, P. (2009). Public health benefits of strategies to reduce greenhouse-gas emissions: overview and implications for policy makers. The Lancet: Health and Climate Change, 374(9797), 2104,2114.

[14] Dadbakhsg, M., Khanjani, N \& Bahrampour, A. (2015). Death from respiratory diseases and air pollutants in Shiraz, Iran (2006-2012). Journal of Environmental Polluyion and Human Health 3(1), 4-11.

[15] Hoek, G., Krishnan, R.M., Beelen, R. et al. Long-term air pollution exposure and cardio- respiratory mortality: a review. Environ Health 12, 43 (2013). https://doi.org/10.1186/1476-069X-12-43

[16] De Sario, M., Katsouyanni, K., \& Michelozzi, P. (2013). Climate change, extreme weather events, air pollution and respiratory health in Europe. European Respiratory Journal, 42(3), 826-843. doi:10.1183/09031936.00074712

[17] Perez-Padilla, R., Schilmann, A \& Riojas-Rodriguez,H. (2010). Respiratory health effects of indoor air pollution. The international journal of Tuberculosis and Lung Disease, 14(9).

[18] Malley, C. S., Henze, D. K., Kuylenstierna, J. C. I., Vallack, H. W., Davila, Y., Anenberg, S. C., ... Ashmore, M. R. (2017). Updated Global Estimates of Respiratory Mortality in Adults $\geq 30$ Years of Age Attributable to Long-Term Ozone Exposure. Environmental Health Perspectives, 125(8), 087021. doi:10.1289/ehp1390 